\title{
Effect of Hydrocarbon Contamination on the Microbial Diversity of Freshwater Sediments Within Akwa Ibom State, Nigeria
}

\author{
Mfoniso Uko ${ }^{1, ~ *, ~ I m e ~ U d o t o n g ~}{ }^{2}$, Utibe Ofon ${ }^{2}$, Senyene Umana ${ }^{1}$, Nsikak Abraham ${ }^{2,3}$ \\ ${ }^{1}$ Department of Microbiology, Faculty of Biological Science, Akwa Ibom State University, Ikot Akpaden, Nigeria \\ ${ }^{2}$ Department of Microbiology, Faculty of Science, University of Uyo, Uyo, Nigeria \\ ${ }^{3}$ Environmental Microbiology and Biotechnology Unit, International Centre for Energy and Environmental Sustainability Research, \\ University of Uyo, Uyo, Nigeria
}

\section{Email address:}

mfonisouko@aksu.edu.ng (M. Uko), Ime.udotong@uniuyo.edu.ng (I. Udotong), utibeofon@uniuyo.edu.ng(U. Ofon), senyeneumana@aksu.edu.ng (S. Umana),nsikabram@yahoo.com (N. Abraham)

${ }^{*}$ Corresponding author

\section{To cite this article:}

Mfoniso Uko, Ime Udotong, Utibe Ofon, Senyene Umana, Nsikak Abraham. Effect of Hydrocarbon Contamination on the Microbial Diversity of Freshwater Sediments Within Akwa Ibom State, Nigeria. Journal of Chemical, Environmental and Biological Engineering. Vol. 4, No. 2, 2020, pp. 32-38. doi: 10.11648/j.jcebe.20200402.11

Received: January 15, 2020; Accepted: February 4, 2020; Published: June 8, 2020

\begin{abstract}
A microbial composition study of sediments of contaminated (CWS) and uncontaminated (UWS) lentic ecosystems within Akwa Ibom State was carried out by analyzing the small-subunit rRNA genes to determine the effect of hydrocarbon contamination on its microbial composition and diversity. Analysis of the V4 region of the community DNA from both sediments revealed the presence of bacteria, archaea and microalgae. Bacterial sequences outnumbered archaea and microalgae. Abundance of Proteobacteria, Betaproteobacteria, Burholderiales, Alcaligenaceae, and Achrombacter were observed in the CWS and Actinobacteria, Actinomycetales, Bacillaceae, and Bacillus in the UWS. Crenarchaeota and Euryarchaeota were also observed to be present in both sediments. The genus Achromobacter and Bacillus dominated in the CWS and UWS, respectively. Uncultured bacterium with the accession number DQ404672.1 and AY917600.1 led at the species levels. Achromobacter sp.-AM232721.1 outnumbered the other species in the CWS such as Kitasatospora sp.AF131379.1, Mycobacterium celatum-AF547908.1, Paenibacillus phyllosphaerae-NR_043008.1, Cystobacter fuscusM94276.1, Planosporangium flavigriseum-NR_042508.1, etc. In the UWS, the dominant species was Bacillus sp.-AJ316313.1. Microalgae, Chlorella sp. and Chlorella vulgaris were also detected in both ecosystems. Diverse and distinct diversity of bacteria, archaea and microalgae are present in the sediments and only a few of them have cultured counterpart. The variation in the microbial communities from the two sites has revealed the impact of contaminants especially hydrocarbons on the microbial diversity in lentic ecosystems.
\end{abstract}

Keywords: Freshwater, Sediment, Hydrocarbon, Prokaryotes, Microalgae, Culture-Independent

\section{Introduction}

Freshwater is an essential resource for life as it serves as both a source of energy and habitat for vast earth's biodiversity. However, it also serves as a sink for several anthropogenic pollutants from agricultural, industrial and municipal activities. These pollutants threaten the survival of most aquatic bodies as well as its biota especially those living in the sediment. In the aquatic ecosystems, sediment composition is largely controlled by hydrodynamic forces than the type of substrate available. For instance, high-energy environments have coarse and sandy substrates with low organic content while silty and muddy sediments with higher organic content accumulate in low-energy environments [1]. These physical differences have direct consequences for the biological community.

In freshwater ecosystems, prokaryotes are among the most important contributors to the transformation of complex 
organic compounds and minerals in the sediments [2]. The metabolic activities of the benthic macro invertebrates living in the sediment strata contribute to aquatic productivity [2]. Freshwater sediments contain enormous variety of species that are involved in several processes such as biodegradation of pollutants, cycling of organic and inorganic compounds thereby maintaining a balance within the ecosystem. These activities help to strike and maintain a balance within the ecosystem. In the oil producing regions, such as the Niger Delta region of Nigeria, these ecological balances are usually altered due to ecological disturbance such as the introduction of pollutants, especially hydrocarbons into the ecosystem [1]. The persistence and subsequent effect of any pollutant in the aquatic ecosystem usually depends on several factors one of which is its sorption to organic matter and sediments [3, 4].

Changes in microbial community in response to introduction of hydrocarbons in marine and fresh water environments have been well documented $[5,6]$ to include increases in bacterial abundance, alteration of enzyme kinetics and other physiological changes [7]. Although microbial communities can adapt to contamination by enrichment of specific species which are able to utilize or resist the toxic effects of the contaminant, increase in the abundance of hydrocarbon-utilizing microorganisms in any ecosystem is usually indicative of petroleum contaminations $[8,9]$.

Studies of the microbial ecosystems in freshwater sediments on the basis of traditional cultivation methods reveal that only $0.25 \%$ of the total cell counts in sediments can be cultured [10], hence, proving limited success in carrying out whole microbial diversity analyses. Sequencing variable regions of the $16 \mathrm{~S}$ rRNA genes has become the predominant tool for studying the ecology of microorganisms [11]. This study examined the microbial composition of two freshwater sediments by metagenomic analysis of the smallsubunit rRNA genes obtained from the sediment samples. The findings of this study will boost our knowledge and deepen understanding of effect of prolong hydrocarbon contamination on the sediment microbial communities of a freshwater ecosystem.

\section{Materials and Methods}

\subsection{Study Area and Site Description}

Two lentic freshwater ecosystems within Akwa Ibom State were selected for this study based on their proximity to petroleum hydrocarbon exploration activities. The first ecosystem which was considered as the contaminated ecosystem (CWS) is located at Inua Eyet Ikot village in Ibeno Local Government Area of Akwa Ibom State. The ecosystem suffers from chronic exposure to hydrocarbon contaminations as the city is a hub for most exploration activities in the state. The second ecosystem which was considered as the uncontaminated ecosystem (UWS) is located at Shelter Afrique estate in Uyo Local Government Area of Akwa Ibom State. This ecosystem is situated within a residential area with no exploration activities within its environs. The coordinates for CWS and UWS are $04^{\circ} 32.647^{\prime}$ $\mathrm{N}, 007^{\circ} 59.951^{\prime} \mathrm{E}$ and $04^{\circ} 58.519^{\prime} \mathrm{N}, 007^{\circ} 57.908^{\prime} \mathrm{E}$ respectively.

\subsection{Sediment Sampling}

Using grab sampler, surface sediments of $5 \mathrm{~cm}$ depth were collected at three different points and mixed to form composite samples for each of the study sites. The samples were preserved in sterile containers and transported on ice to the laboratory. They were kept at $-80^{\circ} \mathrm{C}$ until the extraction of total genomic deoxyribonucleic acid-DNA.

\subsection{Deoxyribonucleic Acid Extraction and Analysis}

The extraction of deoxyribonucleic acid (DNA) from the sediment samples was performed using the Zymo® soil DNA extraction Kit (Model D 6001, Zymo Research, USA) according to the kit protocols as follows: 0.25 grams of sediment was measured into a ZR BashingBead ${ }^{\mathrm{TM}}$ Lysis Tube and $750 \mu \mathrm{l}$ of lysis solution was added and briefly mixed for 5-10 minutes. The mixture was transferred to a bead beater fitted with a $2 \mathrm{ml}$ tube holder assembly and centrifuged at $10,000 \mathrm{x} g$ for 1 minute. Supernatant was centrifuged at 7000 $\mathrm{x} \mathrm{g}$ for 1 minute and $1200 \mu \mathrm{l}$ of DNA binding buffer was added and centrifuged at $10,000 \mathrm{x}$ g for 1 minute. A $200 \mu \mathrm{l}$ of DNA pre-wash buffer was added to the supernatant. This was centrifuged at $10,000 \mathrm{x} \mathrm{g}$ for 1 minute followed by addition of $500 \mu \mathrm{l}$ of DNA wash buffer and another centrifugation at $10,000 \times \mathrm{g}$ for 1 minute. A $100 \mu 1$ of DNA elution buffer was added to the solution in a column matrix and was centrifuged at $10,000 \mathrm{x} \mathrm{g}$ for 30 seconds. The eluted DNA was centrifuged at $8000 \mathrm{x} \mathrm{g}$ for 1 minute. The resulting filtrate gave the genomic DNA (extract). The purity and quantity of the DNA extract was checked by recording its UV absorption spectrum using NanoDrop spectrophotometer and running the DNA in $1 \%$ agarose gel electrophoresis. Analysis of the 16S rRNA gene was performed as described by Udotong et al. [12].

\section{Results}

\subsection{Taxonomical Classification of Microbial Communities of the Study Areas}

Loads of bacterial, archaeal and algal sequences were detected in both sediments through the analysis of the V4 region of 16S rRNA genes of the community DNA isolated from the samples. Although sequences of bacterial communities outnumbered other sequences (Figure 1) in both sediments, the uncontaminated ecosystem (UWS) has a slightly higher bacterial reads $(95.24 \%)$ as compared to that obtained from the contaminated ecosystem (CWS) which had and about $94.13 \%$. On the other hand, archaea and Unknown sequence reads were higher in CWS. These high bacterial communities in the ecosystems agrees to the major roles bacterial communities play in the aquatic ecosystems. According to Diaz and Rosenberg [13] and Urakawa et al. 
[14], bacterial and archaeal populations remain active in mineralization of organic matter and other biogeochemical cycles and are, therefore, important players in the functioning of ecosystems.

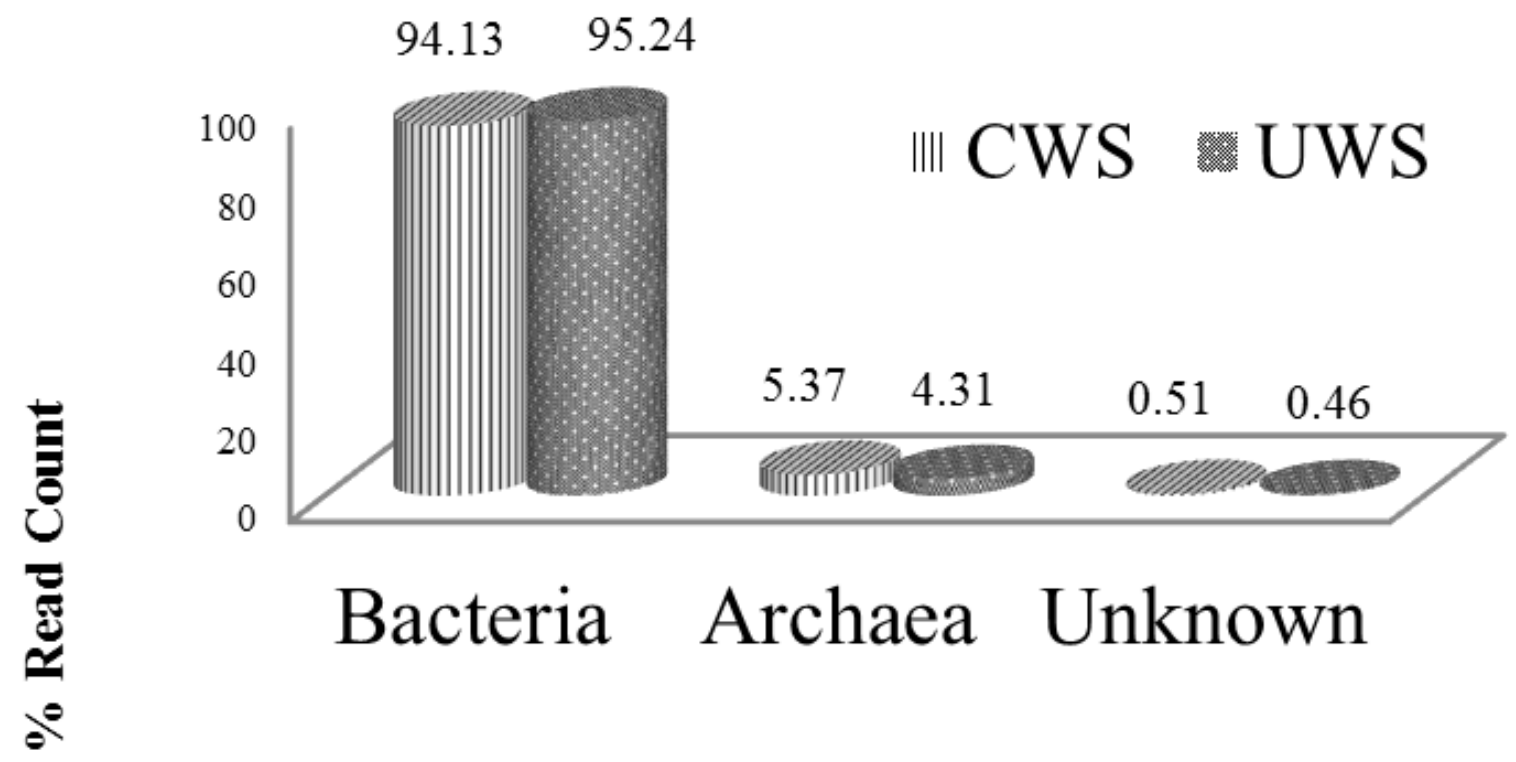

Figure 1. Kingdom classification of gene sequences detected in the contaminated and uncontaminated water sediments.

Although most of the sequences in CWS (57.15\%) and UWS $(64.03 \%)$ fell under an unknown phylum, an abundance of Proteobacteria (24.08\%), Planctomycetes $(2.39 \%)$, Chloroflexi $(1.19 \%)$, Crenarchaeota $(1.12 \%)$ and Acidobacteria (1.1\%) were detected in CWS while Firmicutes (5.65\%) and Actinobacteria (13.52\%) were higher in the uncontaminated ecosystem (UWS) (Figure 2). Betaproteobacteria (16.48\%) was higher in contaminated ecosystem (Figure 3) while Actinobacteria (13.52\%) and Bacilli $(6.94 \%)$ were predominant in UWS. These trends of occurrence in the CWS agree with Udotong et al. [12]. Sequences belonging to archaeal members in the phylum, Crenarchaeota were detected with a percentage composition of $1.12 \%$ in the CWS. Other members of archaea were Euryarchaeota at $0.51 \%$. Euryarchaeota is a member of the group designated 'other' (Figure 2) with a percentage read count of $<1 \%$. Still in the CWS, Methanomicrobia, Methanosarcinales and Methanosarcinaceae were observed at the class, order, and family levels but with percentage read counts of $0.36 \%, 0.36 \%$ and $0.36 \%$ respectively. The activities of these groups of archaea indicate methane production in the ecosystem. Euryarchaeotal and Crenachaeotal sequences were detected in the UWS but at percentage of $0.35 \%$ and $0.29 \%$ respectively. This trend of occurrence in the CWS agrees with Udotong et al. [12].

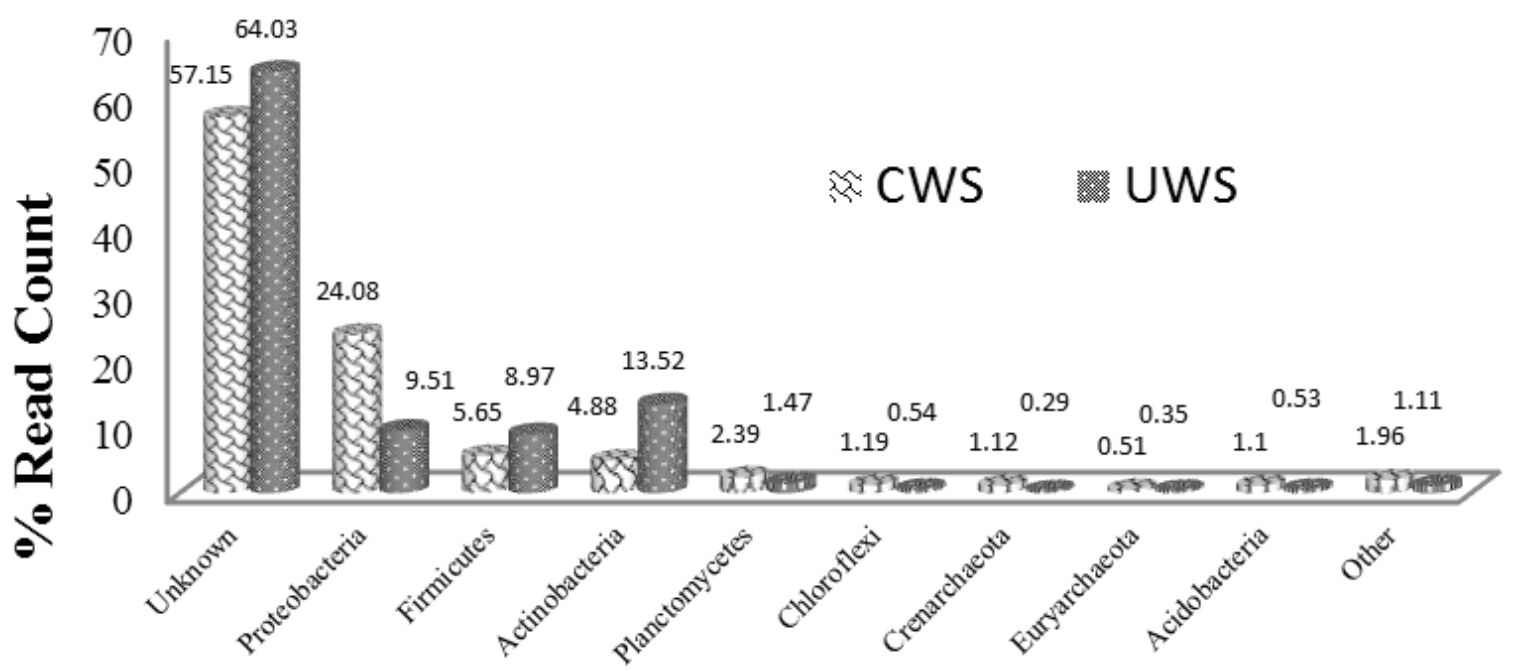

Figure 2. Phyla classification of gene sequences detected in the contaminated and uncontaminated water sediments. Other is the sum of every member with percentage read of $<1$. 


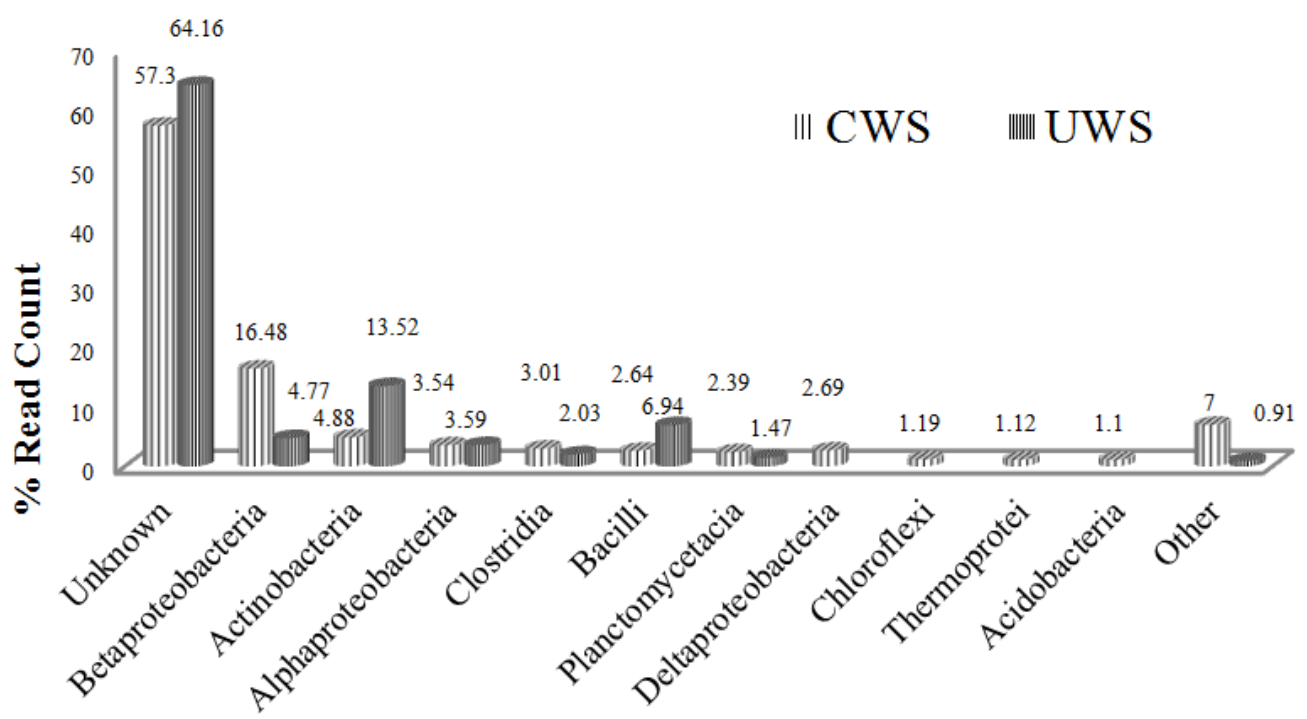

Figure 3. Class classification of gene sequences detected in the contaminated and uncontaminated water sediments. Other is the sum of every member with percentage read of $<1$.

The detection of Planctomycetes in this study confirms their presence as one of the inhabitants in many aquatic habitats including freshwater [15]. They are free-living bacteria with a range of unusual characteristics that set them apart from other bacteria. For example, they are the only bacterial group that lack peptidoglycan in their cell walls, they have various forms of cellular compartmentalization, their genomes tend to be large, and their lipid profiles have many similarities to those of eukaryotic taxa. Species of Planctomycetes are capable of chemolithoautotrophic growth through anaerobic oxidation of ammonium, a process called anammox metabolism where ammonia is oxidized to nitrogen gas by nitrate to yield energy [16]. The prevalent nature of Betaproteobacteria (16.48\%) among the class members in the CWS (Figure 3) agrees with Bucci et al. [17] and $\mathrm{Qu}$ et al., [18]. This validates the high abundance of

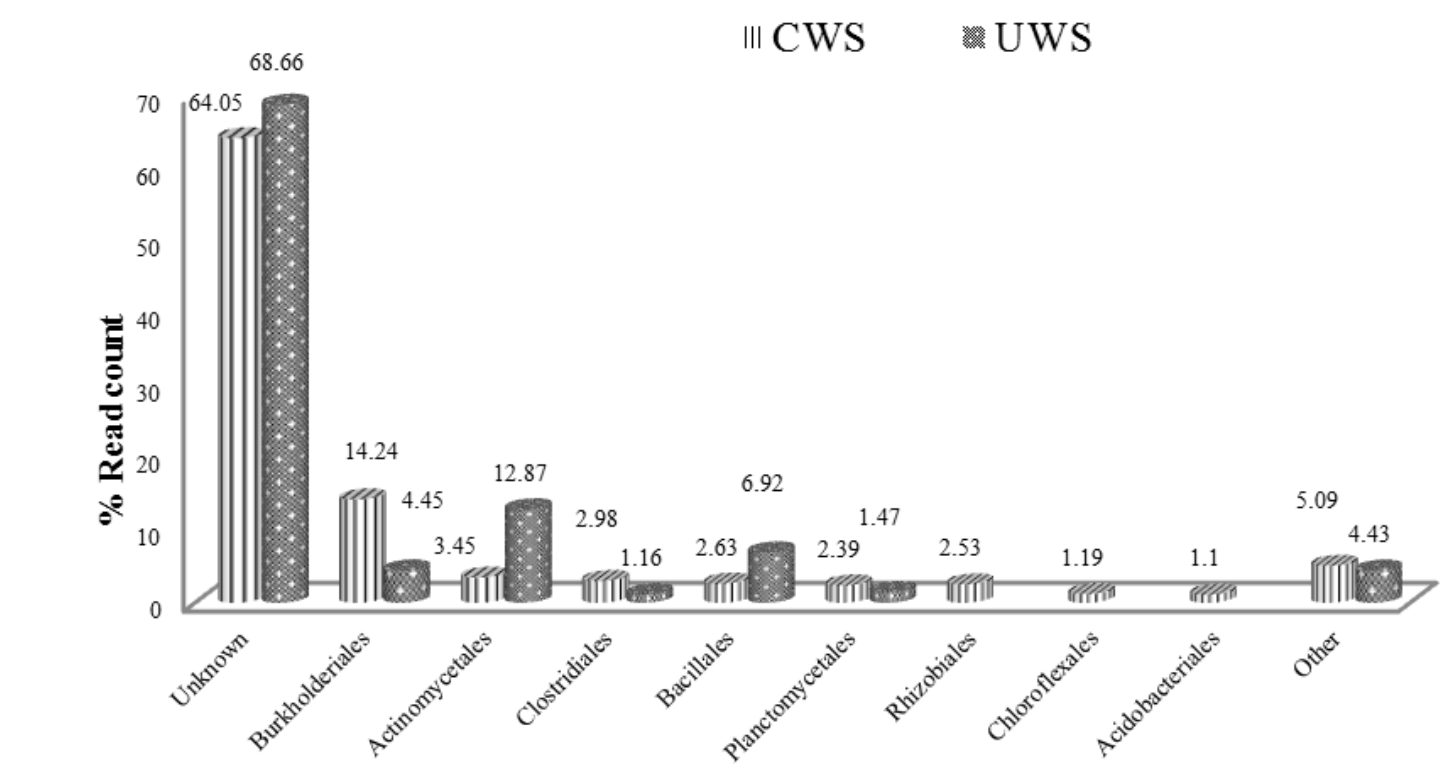

Betaproteobacteria in freshwater ecosystems according to Mueller-and colleagues who also reported that members of Betaproteobacteria outnumber other classes in sediments [19].

Order classification of the sequences revealed the present of Epsilonproteobacteria- $0.45 \%$, Chlamydiae- $0.42 \%$, Methanomicrobia - $0.36 \%$, Bacteroidetes - $0.34 \%$, Nitrospira - $0.16 \%$, etc (Figure 4). Burkholderiales and Actinomycetales accounted for $14.24 \%$ and $3.45 \%$ read count of the CWS, respectively (Figure 4). The occurrence of members of Betaproteobacteria and Burkholderiales in high number as observed in this study confirms the report by Spain et al. [20]. These groups of bacteria are involved in the reduction of nitrate (denitrification) [20], which is one of the important metabolic processes in the sediments.

Figure 4. Order classification of gene sequences detected in the contaminated and uncontaminated water sediments. Other is the total of every member with percentage read of $<1$. 
Alcaligenaceae appeared the most abundant lineage among the family, representing $13.22 \%$ of the prokaryotic reads (Figure 5). Species of the genus Achromobacter, predominated in the CWS, beside the unknown as seen on Figure 6. Sequences belonging to Mycobacterium,
Kitasatospora, Delftia, Zoogloea, Actinomadura, Dechloromonas, Acinetobacter, Neochlamydia, etc. were also discovered in the CWS. Thermanaeromonas, Chlorella, Moorell, Bradyrhizobium, Arthrobacter, and many more were detected in the UWS.

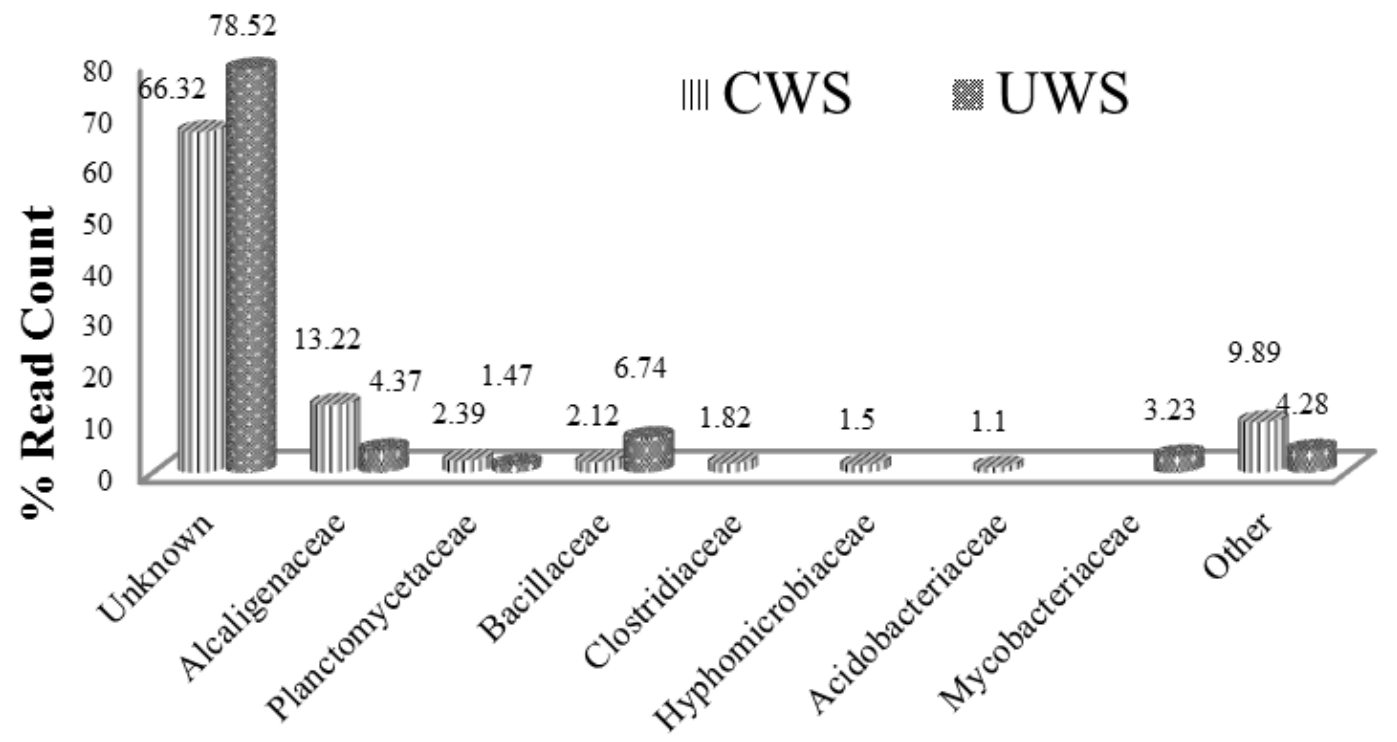

Figure 5. Family classification of gene sequences detected in the contaminated and uncontaminated water sediments. Other is the total of every member with percentage read of $<1$.

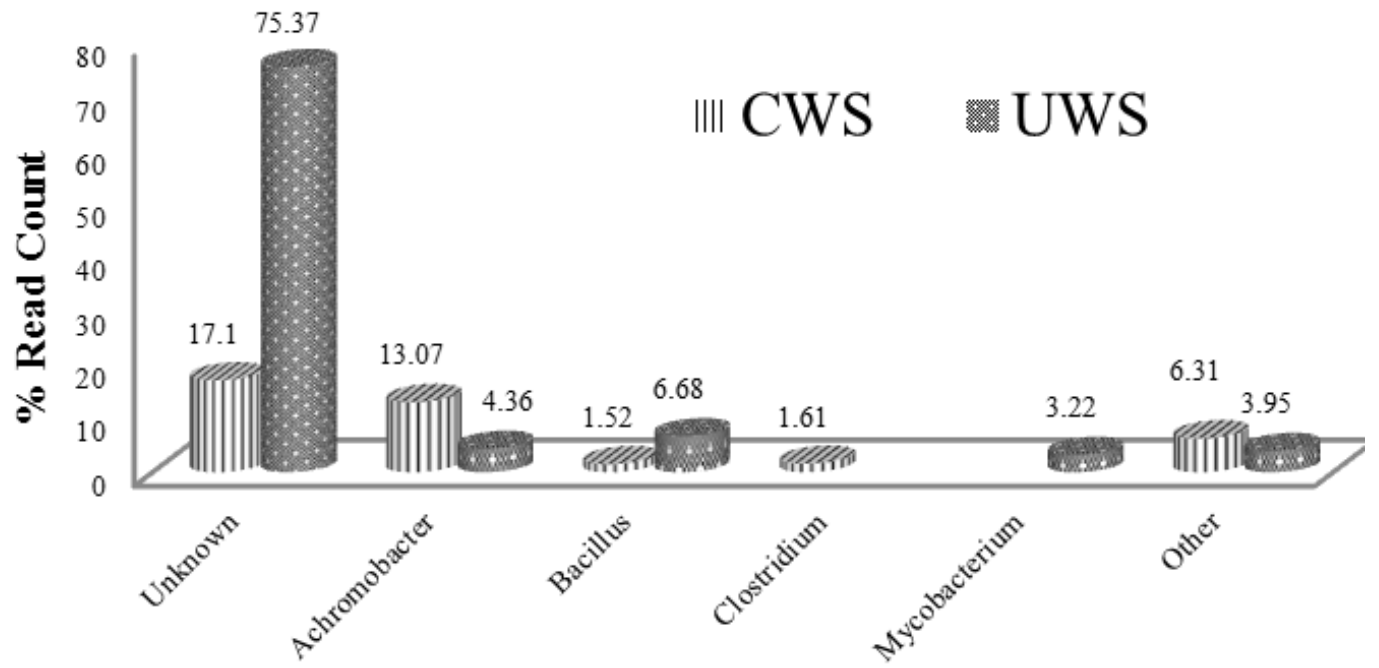

Figure 6. Genera classification of gene sequences detected in the contaminated and uncontaminated water sediments. Other is the total of every member with percentage read of $<1$.

\subsection{Species composition of the Study Area}

Bacterial taxonomic richness, evenness, as well as community composition varied significantly between ecosystems. The species composition of the study area as presented on Table 1 revealed that, besides the Uncultured bacterium (DQ404672.1), Achromobacter sp. (AM232721.1) predominated at the species level with $13.06 \%$ (1325) reads composition in the CWS. Other species members of the CWS ecosystem were Kitasatospora sp.-AF131379.1, Mycobacterium sp.-DQ249999.1, Mycobacterium celatum-
AF547908.1, Paenibacillus phyllosphaerae-NR_043008.1, Cystobacter fuscus-M94276.1, Planosporangium flavigriseum-NR_042508.1, Geobacter pelophilusNR 026077.1, Delftia tsuruhatensis-AJ606337.1, Bacillus sp.-AJ316313.1, Nostoc commune-AB094352.2, among others. The UWS revealed sequences affiliated with Achromobacter sp.-AM232721.1, Mycobacterium sp.DQ249999.1, Mycobacterium celatum-AF547908.1, Cystobacter fuscus-M94276.1, Planosporangium flavigriseum-NR_042508.1, Bacillus sp.-AJ316313.1, Parachlamydia acanthamoebae-NR_026357.1, 
Actinomadura sp.-. AB123461.1, Chlorella sp.-AJ387754.1, Dechloromonas sp.-AF170357.1, Streptomyces sp.AB124430.1, Nostocoida limicola-AF244750.1, Chlorella vulgaris-AJ387750.1, Methylobacterium sp. -AJ627403.1, Rhizobium sp. - AF325769.1, etc. Species of microalgae, Chlorella sp. and Chlorella vulgaris were detected as members of both sediments. Chlorella species are chloroplast-containing microorganisms whose chloroplast genome contains the 16S rRNA gene (sequences) [21] hence, their detection in this study on the basis of their 16S rRNA gene sequences. Observably, Kitasatospora sp.- AF131379.1, Paenibacillus phyllosphaerae- NR_043008.1, Geobacter pelophilus -NR_026077.1, Delftia tsuruhatensis AJ606337.1, Bacillus luciferensis - NR_025511.1, Zoogloea resiniphila- NR_027188.1, Rubrivivax gelatinosusAJ871464.1, Burkholderia gladioli- AB013111.1; and Mycobacterium branderi- AF547906.1, Ammoniphilus oxalivorans- NR_026433.1, and Desulfofustis glycolicusNR_026354.1 are not common to both sediments but associated with the CWS and UWS respectively. Particularly, Zoogloea resiniphila has been recorded in earlier studies (Udotong et al., 2018) as one of the top occurring species in aviation fuel-polluted sediment. This study confirms the species as one of the species linked to aviation fuel-polluted sediments. The variation in the microbial communities from the two sites has revealed the impact of contaminants especially hydrocarbons on the microbial diversity in lentic ecosystems.

Table 1. Some of species members of the microbial communities detected in the contaminated water and uncontaminated water sediments.

\begin{tabular}{|c|c|c|c|}
\hline \multirow{2}{*}{ Species Diversity } & \multicolumn{2}{|c|}{$\%$ Read Count } & \multirow{2}{*}{ Accession Number } \\
\hline & CWS & UWS & \\
\hline Uncultured bacterium & 38.15 & - & DQ404672.1 \\
\hline Uncultured bacterium & - & 42.55 & AY917600.1 \\
\hline Achromobacter sp. & 13.06 & 4.36 & AM232721.1 \\
\hline Unidentified bacterium & 3.56 & 2.67 & AJ518426.1 \\
\hline Kitasatospora sp. & 0.60 & - & AF131379.1 \\
\hline Mycobacterium sp. & 0.48 & 1.44 & DQ249999.1 \\
\hline Paenibacillus phyllosphaerae & 0.05 & - & NR_043008.1 \\
\hline Cystobacter fuscus & 0.01 & 0.01 & M94̄276.1, \\
\hline Planosporangium flavigriseum & 0.04 & 0.05 & NR_042508.1 \\
\hline Geobacter pelophilus & 0.05 & - & NR_026077.1 \\
\hline Delftia tsuruhatensis & 0.43 & - & AJ606337.1 \\
\hline Uncultured archaeon & 3.05 & 3.19 & AJ310451.1 \\
\hline Uncultured planctomycete & 1.98 & 1.37 & AY921762.1 \\
\hline Bacillus sp. & 1.34 & 6.48 & AJ316313.1 \\
\hline Parachlamydia acanthamoebae & 0.12 & 0.01 & NR_026357.1 \\
\hline Bacillus luciferensis & 0.35 & - & NR_025511.1 \\
\hline Zoogloea resiniphila & 0.35 & - & NR_027188.1 \\
\hline Actinomadura sp. & 0.24 & 0.06 & $\mathrm{AB} \overline{1} 23461.1$ \\
\hline Chlorella sp. & 0.16 & 0.17 & AJ387754.1 \\
\hline Dechloromonas sp. & 0.21 & 0.07 & AF170357.1 \\
\hline Streptomyces sp. & 0.17 & 0.07 & $\mathrm{AB} 124430.1$ \\
\hline Rubrivivax gelatinosus & 0.13 & - & AJ871464.1 \\
\hline Nostocoida limicola & 0.12 & 0.05 & AF244750.1 \\
\hline Chlorella vulgaris & 0.01 & - & AF350260.1 \\
\hline Chlorella vulgaris & - & 0.18 & AJ387750.1 \\
\hline Methylobacterium sp. & 0.12 & 0.03 & AJ627403.1 \\
\hline Rhizobium sp. & 0.12 & 0.13 & AF325769.1 \\
\hline Mycobacterium branderi & - & 0.08 & AF547906.1 \\
\hline Clostridium thermosuccinogenes & 0.02 & 0.01 & Y18180.1 \\
\hline Clostridium paraputrificum & 0.01 & 0.29 & NR_026135.1 \\
\hline Ammoniphilus oxalivorans & - & 0.01 & NR_026433.1 \\
\hline Burkholderia gladioli & 0.13 & - & $\mathrm{AB} \overline{0} 13111.1$ \\
\hline Arthrobacter sp. & 0.02 & 0.06 & AB098571.1 \\
\hline Desulfofustis glycolicus & - & 0.01 & NR_026354.1 \\
\hline
\end{tabular}

$-=$ not detected.

\section{Conclusion}

Bacteria, archaea and species of microalgae inhabited the sediments under evaluation. A greater fraction of sequences obtained from the contaminated ecosystem were affiliated with
Proteobacteria while sequence representatives of Actinobacteria predominated in the uncontaminated ecosystem. Sequences of 'Uncultured bacterium' led in both sediments. Sequences affiliated with Achromobacter sp. and Bacillus sp. led other species in the CWS and UWS, respectively. Algae, Chlorella sp. and Chlorella vulgaris were detected in both 
sediments. Kitasatospora sp., Paenibacillus phyllosphaerae, Geobacter pelophilus, Delftia tsuruhatensis, Bacillus luciferensis, Zoogloea resiniphila, Rubrivivax gelatinosus and Burkholderia gladioli were associated with the hydrocarbon contaminated sediments while Mycobacterium branderi, Ammoniphilus oxalivorans, and Desulfofustis glycolicus were associated with the uncontaminated sediments.

\section{Conflict of Interest}

The authors have declared that there is no conflict of interest

\section{References}

[1] Abraham, N. A., Offiong, N. O., Ukafia, O. P. and Akpan, P. E. (2019). Source Apportionment of Polycyclic Aromatic Hydrocarbons (PAHs) in a Tropical Estuarine Epipelic Sediment and Its Associated Bacterial Degrading Potentials. Current Journal of Applied Science and Technology, 32 (1): 111 .

[2] Ezekiel, E. N., Hart, A. I. and Abowei, J. F. N. (2011). The sediment physical and chemical characteristics in Sombreiro River, Niger Delta, Nigeria. Research Journal of Environmental and Earth Sciences, 3 (4), 341-349.

[3] Hassanshahian, M. (2014). The effects of crude oil on marine microbial communities in sediments from the Persian Gulf and the Caspian Sea: A microcosm experiment. International Journal of Advanced Biological and Biomedical Research, 2 (1): 1-17.

[4] Rockne KJ, Shor LM, Young LY, Taghon GL, Kosson DS (2002) Distributed Sequestration and Release of PAHS in Weathered Sediment: The Role of Sediment Structure and Organic Carbon Properties. Environmental Science and Technology, 36: 2636-2644.

[5] Hara, A., Syutsubo, K. and Harayama, S. (2003). Alcanivorax which prevails in oil-contaminated seawater exhibits broad substrate specificity for alkane degradation. Environmental Microbiology, 5 (9): 746-753.

[6] Ghanavati, H., Emtiazi, G. and Hassanshahian, M. (2008). Synergism effects of phenol degrading yeast and Ammonia Oxidizing Bacteria for nitrification in coke wastewater of Esfahan Steel Company. Waste Management Resource, 26: 203-208.

[7] Labud, V., Garcia, C. and Hernandez, T. (2007). Effect of hydrocarbon pollution on the microbial properties of a sandy and a clay soil. Chemosphere, 66: 1863-1871.

[8] Margesin, R., Labbe, D., Schinner, F. C., Greer, W. and Whyte, L. G. (2003) Characterization of hydrocarbondegrading microbial populations in contaminated and pristine alpine soils. Applied Environmental Microbiology, 69: 30853092.

[9] Cappello, S., Caruso, G., Zampino, D., Monticelli, L. S., Maimone, G., Denaro, R., Tripodo, B., Troussellier, M., Yakimov, M. M. and Giuliano, L. (2007). Microbial community dynamics during assays of harbour oil spill bioremediation: a microscale simulation study. Journal of Applied Microbiology, 102 (1): 184-194.
[10] Amann, R. I., Ludwig, W. and Schleifer, K. H. (1995). Phylogenetic identification and in situ detection of individual microbial cells without cultivation. Microbiology Reviews, 59: $143-169$.

[11] Zhang, J., Ding, X., Guan, R., Zhu, C., Xu, C., Zhu, B., Zhang, H., Xiong, Z., Xue, Y., Tu, J. and Lu, Z. (2018). Evaluation of different $16 \mathrm{~S}$ rRNA gene $\mathrm{V}$ regions for exploring bacterial diversity in a eutrophic freshwater lake. Science of Total Environment, 618: 1254-1267.

[12] Udotong, I. R., Uko, M. P. and Udotong, J. I. R. (2015). Microbial diversity of a remote aviation fuel-contaminated sediment of a lentic ecosystem in Ibeno, Nigeria. Journal of Environmental and Analytical Toxicology, 5: 320.

[13] Diaz, R. J. and Rosenberg, R. (2008). Spreading dead zones and consequences for marine ecosystems. Science 321: 926929.

[14] Urakawa, H., Martens-Habbena, W. and Stahl, D. A. (2010). High abundance of ammonia-oxidizing Archaea in coastal waters, determined using a modified DNA extraction method. Applied and Environmental Microbiology, 76: 2129-35.

[15] Pollet, T., Tadonléké, R. D. and Humbert, J. F. (2011). Comparison of primer sets for the study of Planctomycetes communities in lentic freshwater ecosystems. Environmental Microbiology Reports, 3 (2) 254-261.

[16] Buckley, D. H., Huangyutitham, V., Nelson, T. A., Rumberger, A., Thies, J. E. (2006). Diversity of planctomycetes in soil in relation to soil history and environmental heterogeneity. Applied and Environmental Microbiology, 72 (7), 4522-4531.

[17] Bucci, J. P., Szempruch, A. J., Caldwell, J. M., Ellis, J. C. and Levine, J. F. (2014). Seasonal changes in microbial community structure in freshwater stream sediment in a North Carolina River Basin. Diversity, 6: 18-32.

[18] Qu, J., Zhang, Q., Zhang, N., Shen, L. and Liu, P. (2015). Microbial community diversity in water and sediment of a eutrophic lake during harmful algal bloom using MiSeq illumina. technology. International Conference on Advances in Environment Research. 87 (12).

[19] Mueller-Spitz, S. R., Goetz, G. W. and McLellan, S. L. (2009) Seasonal and spatial variability in nearshore bacterioplankton communities of lake Michigan. FEMS Microbiology Ecology, 67: 511-522.

[20] Spain, A. M., Peacock, A. D., Istok, J. D., Elshahed, M. S., Najar, F. Z., Roe, B. A., White, D. C. and Krumholz, L. R. (2007). Identification and isolation of a Castellaniella species important during biostimulation of an acidic nitrate- and uranium-contaminated aquifer. Applied and Environmental Microbiology, 73: 4892-4904.

[21] Burja, A. M., Tamagnini, P., Bustard, M. T. and Wright, P. C. (2001). Identification of the green alga, Chlorella vulgaricus (SDC1) using cyanobacteria derived 16S rDNA primers: targeting the chloroplast. FEMS Microbiology Letters, 202: 195-203.

[22] Udotong, I. R., Uko, M. P. and Udotong, J. I. R. (2018). Prokaryotic Diversity of a Remote Aviation Fuel-Polluted Lentic Ecosystem in Ibeno, Medical and Clinical Research, 3: $1-5$. 